\title{
NILAI HERITABILITAS DAN RESPONS SELEKSI POPULASI F-3 BENIH IKAN NILA BIRU (Oreochromis aureus) PADA FASE PENDEDERAN
}

\author{
Bambang Gunadi", Adam Robisalmi, Priadi Setyawan, dan Lamanto \\ Balai Penelitian Pemuliaan Ikan \\ (Naskah diterima: 20 Februari 2015; Revisi final: 29 Mei 2015, Disetujui publikasi: 5 Juni 2015)
}

\begin{abstract}
ABSTRAK
Salah satu upaya meningkatkan performa ikan nila Srikandi (Oreochromia aureus x Oreochromia niloticus), yang dirilis oleh Balai Penelitian Pemuliaan Ikan (BPPI) Sukamandi pada tahun 2012, adalah dengan meningkatkan keragaan genetik ikan nila biru (Oreochromis aureus), salah satu strain pembentuknya. Peningkatkan kualitas genetik ikan nila biru dapat dilakukan dengan program seleksi. Penelitian ini bertujuan untuk mengetahui nilai heritabilitas, serta respons seleksi benih ikan nila biru F-3 pada fase pendederan. Kegiatan pembenihan dilakukan di air tawar dengan wadah pemijahan berupa hapa $1 \mathrm{~m} \times 1 \mathrm{~m} \times 1 \mathrm{~m}$. Induk jantan dan betina dipijahkan secara berpasangan dengan perbandingan $1: 1$. Larva dipanen pada hari ke10 sampai ke-15, dan selanjutnya dipelihara di hapa pendederan berukuran $2 \mathrm{~m}$ x $2 \mathrm{~m}$ x $1 \mathrm{~m}$ selama 90 hari dengan padat tebar $125 \mathrm{ekor} / \mathrm{m}^{2}$. Selanjutnya benih dikelompokkan berdasarkan jenis kelamin jantan dan betina pada masing-masing famili. Paramater yang diamati meliputi pertumbuhan bobot dan panjang, koefisien keragaman (KK) panjang dan bobot, nilai heritabilitas nyata dan respons seleksi. Hasil penelitian menunjukkan ikan nila biru F-3 hasil seleksi mempunyai performa lebih baik dibandingkan nila biru nonseleksi. Pada akhir masa pemeliharaan, rataan bobot individu benih F-3 seleksi adalah sebesar 11,58 $\pm 2,54 \mathrm{~g}$; sementara pada populasi non-seleksi (kontrol) sebesar 8,95 $\pm 2,80 \mathrm{~g}$. Benih F-3 mempunyai nilai KK panjang dan bobot masing-masing sebesar 4,94\%-25,05\% dan 19,62\%-53,47\%. Nilai heritabilitas nyata pada populasi F-3 benih nila biru sebesar 0,81 dengan respons seleksi sebesar 2,63 g atau 22,74\%.
\end{abstract}

KATA KUNCI: heritabilitas, respons seleksi, benih nila biru (Oreochromis aureus), pendederan

ABSTRACT: Heritability and response of selection of F-3 population of blue tilapia (Orechromis aureus) fry in the fingerling stage. By: Bambang Gunadi, Adam Robisalmi, Priadi Setyawan, and Lamanto

Research Institute for Fish Breeding (Sukamandi, West Java, Indonesia) had released a salinity tolerant tilapia strain which was later well known as "Srikandi" tilapia hybrid between Oreochromis aureus $x$ Oreochromis niloticus) in 2012. This hybrid tilapia was formed from the parent stock of female nile tilapia (Oreochromia niloticus) and male blue tilapia (Oreochromis aureus). Thus, increasing the performance of Srikandi tilapia can be achieved by genetical improvement of blue tilapia, which can be conducted through selection. This experiment was aimed to find the value of heritability and response of selection of the third generation (F-3) of blue tilapia fry during fingerling stage (90 days old). The broodstock fish were spawned in hapas sized of $1 \mathrm{~m} \times 1 \mathrm{~m} \times 1 \mathrm{~m}$, where male and female of blue tilapia were mated separately with a ratio of 1 male to 1 female. Released larvae were harvested after 10-15 days post mating. The larvae from one family were then reared in separate hapas sized of $2 m \times 2 m \times 1 m$ for 90 days with a stocking density of 125 larvae $/ \mathrm{m}^{2}$. After 90 days of rearing period, fish fry were grouped base on their sex, i.e. male and female. The observation carried out on weight and length growth, coefficient of variation of weight and length, heritability, and response of selection. The results showed that the selected population of blue tilapia F-3 grew better than non selected population. The average of final body weight of selected and non selected population of blue tilapia F-3 fingerling were $11.58 \pm 2.54 \mathrm{~g}$ and $8.95 \pm 2.80 \mathrm{~g}$, respectively. The coefficient of variation of length and weight of blue tilapia F-3 fingerling were 4.94\%-25.05\% and 19.62\%-53.47\%, respectively. The blue tilapia F-3 population had a heritability value of 0.81 and response of selection of $2.63 \mathrm{~g}$ or $22.74 \%$.

KEYWORDS: $\quad$ heritability, response of selection, blue tilapia (Orechromis aureus), fingerling stage

\# Korespondensi: Balai Penelitian Pemuliaan Ikan.

Jl. Raya Sukamandi No. 2, Subang 41256, Indonesia.

Tel.: + (0260) 520500

E-mail: bgunadi@kkp.go.id 


\section{PENDAHULUAN}

Ikan nila biru (Oreochromis aureus) merupakan salah satu strain pembentuk ikan nila Srikandi (O. niloticus x 0 . aureus) yang mempunyai keunggulan tumbuh cepat pada salinitas tinggi dan telah dirilis oleh Balai Penelitian Pemuliaan Ikan, Sukamandi pada tahun 2012. Ikan nila biru memiliki keunggulan dapat dipelihara di perairan payau dan laut (Shafland \& Pesytrak, 1982). Ikan nila biru dilaporkan dapat dibudidayakan di Laut Tampa (Florida, Amerika Serikat), tumbuh baik pada kisaran salinitas 36-44 ppt dengan reproduksi optimum terjadi pada salinitas 19 ppt. Selain itu, dengan aklimatisasi secara bertahap, nila biru dapat tumbuh dengan baik sampai salinitas 54 ppt (Balarin \& Haller, 1982; Courtenary et al., 1984).

Untuk mempertahankan dan meningkatkan performa ikan nila Srikandi perlu dilakukan peningkatan kualitas genetik induk-induk pembentuknya. Salah satu cara untuk meningkatkan kualitas genetik ikan nila biru adalah dengan program seleksi. Pada dasarnya program seleksi dapat dibedakan menjadi dua salah satunya adalah seleksi famili. Dalam melakukan seleksi famili, hubungan famili merupakan faktor yang penting, di mana rata-rata famili dijadikan acuan untuk mengambil keputusan selanjutnya. Pengambilan keputusan dapat dikelompokkan menjadi antar famili (between family) dan dalam famili (within family). Gabungan antara antar dan dalam famili disebut kombinasi antar dan dalam famili. Jenis seleksi lainnya meliputi tandem, independent culling, dan selection index yang merupakan variasi dari kedua bentuk seleksi tersebut (Tave, 1995; Gjedrem, 2005). Sebelum menetapkan metode pemuliaan dan seleksi yang akan digunakan, serta kapan seleksi akan dimulai, perlu diketahui berapa besar keragaman genetik. Selain itu, perlu juga diketahui nilai heritabilitas karakterkarakter yang akan dijadikan target seleksi (Pinaria et al., 1995).

Pada tahun 2013 telah dihasilkan populasi terseleksi ikan nila biru jantan dan betina F-2 dengan estimasi nilai heritabilitas yang masih positif pada generasi selanjutnya sehingga kegiatan seleksi famili tetap dilakukan untuk mendapatkan populasi turunannya yang memiliki pertumbuhan lebih tinggi lagi pada salinitas 25-30 ppt. Sebagai tahap awal dilakukan kegiatan pemijahan dan pendederan benih ikan nila biru di kolam air tawar sebelum masuk ke pembesaran di tambak. Penelitian ini bertujuan untuk mengetahui nilai heritabilitas dan respons seleksi benih nila biru F-3 selama fase pendederan.

\section{BAHAN DAN METODE}

Penelitian ini dilakukan di Balai Penelitian Pemuliaan Ikan, Sukamandi. Induk yang digunakan meru- pakan induk ikan nila biru F-2 hasil seleksi yang dipelihara di tambak bersalinitas 25-30 ppt di Brebes. Kegiatan pemijahan, pemeliharaan benih, dan pendederan dilakukan di kolam air tawar di Sukamandi.

\section{Pembenihan}

Pembentukan populasi F-3 ikan nila biru toleran salinitas tinggi dalam kegiatan penelitian ini dilakukan dengan metode seleksi dalam famili (within family). Ikan uji yang digunakan adalah ikan nila biru (Oreochromis aureus) populasi F-2 terseleksi dan induk F-2 non seleksi sebagai populasi kontrol. Induk-induk yang digunakan merupakan hasil pembesaran di tambak bersalinitas 25-30 ppt selama tiga bulan. Setelah dipanen, induk-induk diadaptasikan ke kolam air tawar sebelum dilakukan pemijahan. Jumlah induk yang dipijahkan sebanyak 90 ekor jantan dan 90 ekor betina. Induk-induk yang memijah dalam kurun waktu lima hari dimasukan dalam satu cohort.

Kegiatan pemijahan tiap-tiap famili dilakukan di hapa berukuran $1 \mathrm{~m}$ x $1 \mathrm{~m}$ x $1 \mathrm{~m}$ dengan perbandingan induk jantan dan betina adalah $1: 1$. Induk jantan yang digunakan berukuran $300 \mathrm{~g}$ dan induk betina $250 \mathrm{~g}$. Sebelum dilakukan pemijahan, terlebih dahulu dilakukan pemotongan pre maxila (bibir) induk jantan dengan tujuan untuk menghindari adanya luka yang menyebabkan kematian pada induk betina akibat serangan induk jantan. Pemanenan larva dilakukan pada hari ke-10 sampai ke-15 setelah melihat adanya kemunculan larva di atas permukaan air. Larva yang diperoleh dari dua pasang induk dijadikan satu famili. Larva hasil koleksi dari masing-masing famili dipelihara dalam hapa pendederan berukuran $2 \mathrm{~m} \mathrm{x} 2 \mathrm{~m} \mathrm{x}$ $1 \mathrm{~m}$ selama 90 hari dengan padat tebar $125 \mathrm{ekor} / \mathrm{m}^{2}$. Pakan yang digunakan untuk pendederan berkadar protein $40 \%$ dengan frekuensi pemberian pakan sebanyak tiga kali sehari secara at satiation (sampai kenyang). Pengamatan panjang standar (Standard Length, $S L$ ); panjang total (Total Length, $T L$ ); dan bobot badan (Body Weight, BW) ikan dilakukan setiap 30 hari. Sintasan dihitung berdasarkan pada jumlah ikan yang mati secara akumulatif setelah 90 hari pemeliharaan. Pada akhir masa 90 hari pemeliharaan, dilakukan proses pemisahan populasi berdasarkan kelamin antara jantan dan betina.

\section{Seleksi}

Proses seleksi dilakukan pada umur 90 hari pada karakter bobot. Seleksi dibedakan antara jantan dan betina, karena ikan nila jantan dan betina memiliki tingkat pertumbuhan yang berbeda. Dari setiap famili, diambil sampel secara acak sebanyak 25-30 ekor individu kemudian dilakukan pengukuran terhadap bobot sehingga diperoleh data distribusi ukuran yang selanjutnya diurutkan dari nilai terkecil hingga ter- 
besar. Berdasarkan urutan data distribusi tersebut, ditetapkan batas minimum ukuran ikan yang akan diseleksi, yaitu $10 \%$ individu jantan dengan keragaan fenotipe terbaik dari populasi. Prosedur yang sama diterapkan untuk memilih individu betina. Berdasarkan ukuran batas minimum yang telah diperoleh, dilakukan seleksi terhadap seluruh populasi.

\section{Analisis Data}

Parameter yang diamati meliputi: koefisien keragaman, diferensial seleksi, respons seleksi, dan nilai heritabillitas nyata serta estimasi heritabilitas dilakukan dengan formula sebagai berikut:

- Koefisien keragaman (CV) dihitung dengan menggunakan rumus Singh \& Chaudary (1977):

$$
C V=\frac{S D}{X} \times 100 \%
$$

di mana:

$\mathrm{CV}=$ Koefisien keragaman

$\mathrm{SD}=$ Standar deviasi

$\mathrm{X}=$ Rataan populasi

- Nilai diferensial seleksi (S), dihitung berdasarkan bobot rata-rata populasi awal dan bobot rata-rata populasi terseleksi. Nilai diferensial seleksi dihitung berdasarkan formula sebagai berikut:

$$
S=x^{\prime}-x
$$

di mana:

$\mathrm{S}=$ Diferensial seleksi

$\mathrm{x}^{\prime}=$ Rata-rata bobot populasi terseleksi

$\mathrm{x}=$ Rata-rata bobot populasi awal
- Heritabilitas nyata $\left(\mathrm{h}^{2}\right)$, dihitung dengan rumus Falconer (1981) sebagai berikut:

$$
\mathrm{h}^{2}=\frac{\mathrm{r}}{\mathrm{s}}
$$

di mana:

$$
\begin{aligned}
& \mathrm{h}^{2}=\text { Heritabilitas nyata } \\
& \mathrm{r}=\text { Respons seleksi } \\
& \mathrm{s}=\text { Diferensial seleksi populasi F-2 }
\end{aligned}
$$

\section{HASIL DAN BAHASAN}

Pola pertumbuhan bobot populasi benih ikan nila biru F-3 seleksi dan kontrol dicantumkan pada Gambar 1. Populasi ikan nila biru seleksi tumbuh lebih baik dengan rataan bobot individu akhir sebesar $11,58 \pm 2,54 \mathrm{~g}$; sementara pada populasi kontrol rataan bobot individu akhirnya adalah $8,95 \pm 2,80 \mathrm{~g}$. Dengan kondisi lingkungan dan manajemen yang sama, perbedaan pertumbuhan ikan nila biru dalam penelitian ini lebih banyak ditentukan oleh faktor keturunan atau genetik. Hal ini menunjukkan adanya peningkatan performa pada populasi F-3 dibanding generasi sebelumnya. Tersedianya pakan alami dan pemberian pakan berupa pelet dengan kadar protein tinggi $(40 \%)$ membuat kebutuhan energi untuk tumbuh dapat terpenuhi secara optimal.

Faktor yang memengaruhi pertambahan bobot ikan antara lain keturunan dan lingkungan. Faktor lingkungan yang memengaruhi pertumbuhan ikan antara lain makanan, ruang, suhu, salinitas, musim, dan aktivitas fisik (Gilles, 1987). Kamel et al. (2008) melaporkan bahwa juvenil ikan nila biru yang dipelihara pada kolam dengan kedalaman air $70 \mathrm{~cm}$ mempunyai rerata bobot akhir sebesar $4,7 \mathrm{~g}$ dan pertum-

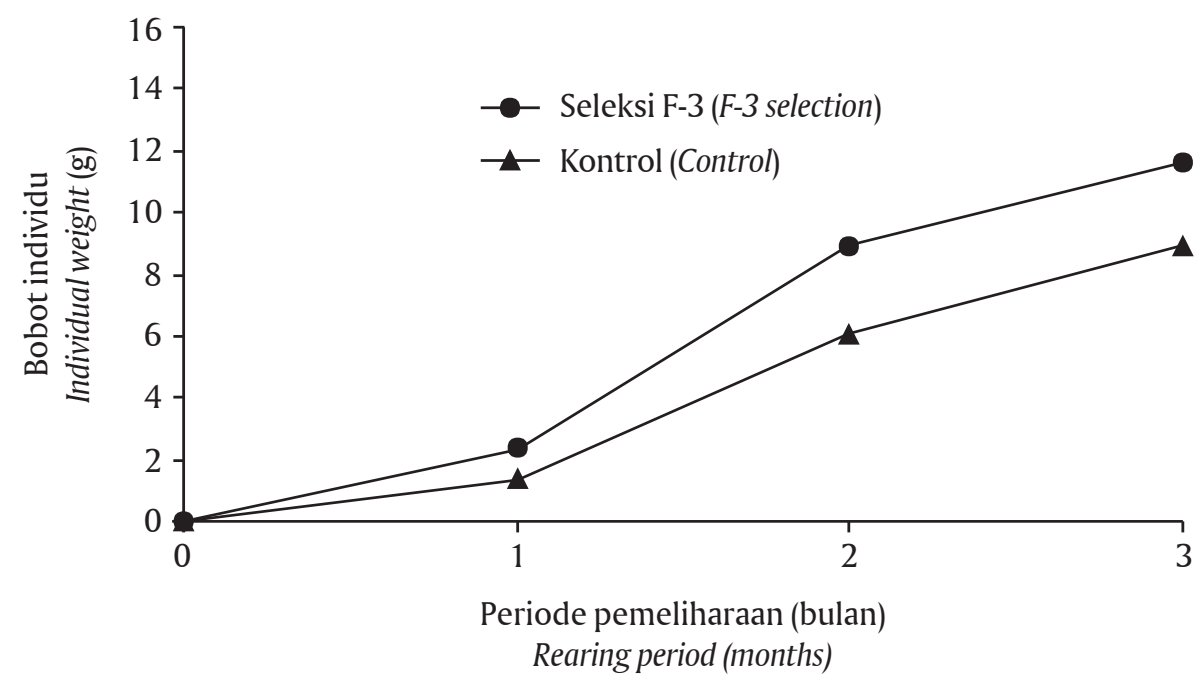

Gambar 1. Pertumbuhan benih ikan nila biru (Oreochromis aureus) populasi F-3 seleksi dan populasi kontrol selama tiga bulan masa pemeliharaan

Figure 1. The growth of selected and non-selected (control) of F-3 population of blue tilapia (Oreochromis aureus) for three months rearing period 
buhan bobot mutlak sebesar 3,3 g diikuti dengan sintasan yang tinggi 80,9\%.

Pada penelitian ini, dari 17 famili yang dipelihara dalam tahap pendederan, sebanyak sepuluh famili dapat digunakan untuk seleksi. Sementara, tujuh famili yang lain memiliki umur yang berbeda. Untuk mengetahui seberapa besar ukuran panjang dan bobot badan ikan dalam satu famili menyebar dari nilai rata-ratanya maka dihitung nilai koefisien keragaman (KK). Pada populasi benih ikan nila biru F-3 nilai koefisien keragaman panjang secara umum berkisar dari 4,94\%-25,05\%; sedangkan pada karakter bobot berkisar antara 19,62\%-53,47\% (Tabel 1). Nilai KK ini termasuk ke dalam kategori rendah sampai sedang pada karakter panjang dan sedang sampai tinggi untuk karakter bobot. Tampake et al. (1992) menentukan keragaman suatu karakter dengan kriteria rendah jika $\mathrm{KK}=0 \%-20 \%$, sedang jika $\mathrm{KK}=20 \%-50 \%$ dan tinggi jika $\mathrm{KK}=>50 \%$.

Nilai koefisien keragaman menunjukkan nilai keragaman dari populasi yang diukur, di mana semakin tinggi nilai koefisien variasi menunjukkan bahwa populasi yang diukur memiliki keragaman yang luas atau lebih heterogen, sedangkan jika nilai koefisien keragaman rendah artinya populasi yang diukur mempunyai nilai keragaman yang sempit atau lebih homogen. Bahar \& Zen (1993) berpendapat bahwa heritabilitas tinggi dan ragam genetik tinggi pada umumnya akan mempunyai koefisien keragaman genetik (KKG) tinggi. Keberhasilan program pemuliaan

Tabel 1. Nilai koefisien keragaman karakter panjang dan bobot benih ikan nila biru populasi F-3 pada umur 90 hari

Table 1. Coefficient of variation of length and weight characters of F-3 population of blue tilapia at 90 days old

\begin{tabular}{ccc}
\hline \multirow{2}{*}{$\begin{array}{c}\text { Kode famili } \\
\text { Family code }\end{array}$} & \multicolumn{2}{c}{$\begin{array}{c}\text { Koefisien keragaman } \\
\text { Coefficient of }\end{array}$} \\
\cline { 2 - 3 } & $\begin{array}{c}\text { Panjang } \\
\text { Length } \mathbf{( c m )}\end{array}$ & $\begin{array}{c}\text { Bobot } \\
\text { Weight }(\mathbf{g})\end{array}$ \\
\hline Famili (Family) 1 & 9.74 & 30.72 \\
Famili (Family) 2 & 10.43 & 28.09 \\
Famili (Family) 3 & 8.90 & 20.56 \\
Famili (Family) 4 & 23.44 & 25.33 \\
Famili (Family) 5 & 25.05 & 45.55 \\
Famili (Family) 6 & 15.61 & 53.47 \\
Famili (Family) 7 & 4.94 & 22.34 \\
Famili (Family) 8 & 7.44 & 19.62 \\
Famili (Family) 9 & 7.54 & 22.25 \\
Famili (Family) 10 & 7.90 & 24.07 \\
\hline
\end{tabular}

sangat ditentukan oleh tersedianya keragaman genetik. Semakin tinggi keragaman genetik yang dimiliki semakin besar peluang keberhasilan program pemuliaan. Keragaman yang tinggi juga dapat meningkatkan respons seleksi karena respons seleksi berbanding lurus dengan keragaman populasi.

Pada populasi F-3 ikan nila biru seleksi, nilai KK bobot lebih tinggi dibanding panjang, sehingga dapat dikatakan karakter bobot lebih beragam dan menyebar luas dibanding karakter panjang. Hal ini menunjukkan harapan besar terhadap keberhasilan program seleksi. Menurut Tave (1993), koefisien keragaman (coefficient of variation) memberikan gambaran keragaman fenotipe yang akan mendukung keberhasilan suatu program seleksi. Semakin tinggi nilai koefisien keragaman dalam suatu populasi maka hal itu semakin menunjukkan keberagaman ukuran individu dalam populasi tersebut dan menjadikan populasi itu untuk kandidat yang akan diseleksi atau sebagai populasi untuk seleksi berikutnya.

Berdasarkan data bobot rata-rata pada masingmasing famili dilakukan cut-off untuk melakukan seleksi. Adapun batas minimum ukuran ikan yang akan diseleksi, yaitu $10 \%$ dari populasi tiap-tiap famili yang memiliki keragaan fenotipe (karakter bobot) terbaik dari populasi. Hasil cut-off pada populasi benih ikan nila biru F-3 diperoleh rataan bobot terseleksi dari masing-masing famili berkisar dari $12,16 \pm 1,82 \mathrm{~g}$ sampai 34,18 $\pm 2,54 \mathrm{~g}$ dengan nilai diferensial seleksi berkisar antara 4,48-10,34 $\mathrm{g}$ (Tabel 2).

Keberhasilan program pemuliaan sangat ditentukan oleh tersedianya ragam genetik. Pada penelitian ini diketahui nilai koefisien keragaman genotipe bobot pada populasi benih ikan nila biru F-3 sebesar $29,20 \%$ lebih tinggi dibanding keragaman fenotipenya $12,10 \%$.

Menurut Charo-Karisa et al. (2006), proses inbreeding pada proses seleksi ini lebih dikendalikan untuk mengeksploitasi keunggulan genetik dan melepaskan sifat genetik yang tidak diinginkan pada setiap famili. Sehingga pada setiap generasi inbreeding hanya sifat yang unggul yang dipilih sedangkan sifat yang tidak unggul tidak dipilih. Dengan seleksi inbreeding yang terus-menerus selama beberapa generasi akan dihasilkan famili yang memiliki tingkat kemurnian lebih tinggi dengan karakter keunggulannya dan membentuk populasi induk sebagai induk penjenis. Sedangkan induk pokok dihasilkan dari hasil blending populasi famili yang memiliki keragaman genetik yang tinggi. Untuk meningkatkan kemurniannya, maka proses seleksi perlu dilanjutkan untuk menghasilkan generasi F-4. Bila pada F-4 dapat menghasilkan famili dengan hereditas yang lebih tinggi dan respons seleksi yang lebih besar, maka generasi F-4 
Tabel 2. Nilai cut-off, bobot rata-rata populasi, bobot rata-rata terseleksi, dan diferensial seleksi populasi ikan nila biru F-3 fase pendederan

Table 2. The value of cut-off, the average population weight, the average of selected population weight, and differential selection of the F-3 population of blue tilapia in the fingerling stage

\begin{tabular}{ccccc}
\hline $\begin{array}{c}\text { Kode famili } \\
\text { Family code }\end{array}$ & $\begin{array}{c}\text { Cut-off } \\
\mathbf{( g )}\end{array}$ & $\begin{array}{c}\text { Rataan bobot } \\
\text { individu populasi } \\
\text { Average of individual } \\
\text { weight of population }(\mathbf{g})\end{array}$ & $\begin{array}{c}\text { Rataan bobot } \\
\text { individu terseleksi } \\
\text { Average of selected } \\
\text { individual weight } \text { (g) }\end{array}$ & $\begin{array}{c}\text { Diferensial seleksi } \\
\text { Selection differential (g) }\end{array}$ \\
\hline Famili (Family) 1 & 13.96 & $9.54 \pm 2.93$ & $14.02 \pm 0.86$ & 4.48 \\
Famili (Family) 2 & 18.74 & $13.82 \pm 3.88$ & $20.11 \pm 2.09$ & 6.29 \\
Famili (Family) 3 & 28.31 & $23.54 \pm 4.84$ & $29.67 \pm 1.30$ & 6.13 \\
Famili (Family) 4 & 32.27 & $25.34 \pm 6.42$ & $34.18 \pm 2.54$ & 8.84 \\
Famili (Family) 5 & 24.6 & $15.86 \pm 7.22$ & $26.21 \pm 2.30$ & 10.35 \\
Famili (Family) 6 & 19.47 & $11.87 \pm 6.31$ & $21.51 \pm 2.16$ & 9.64 \\
Famili (Family) 7 & 18.94 & $14.24 \pm 3.18$ & $19.52 \pm 1.51$ & 5.28 \\
Famili (Family) 8 & 17.63 & $15.55 \pm 3.05$ & $20.88 \pm 2.75$ & 5.33 \\
Famili (Family) 9 & 20.66 & $16.14 \pm 3.59$ & $21.64 \pm 1.60$ & 3.66 \\
Famili (Family) 10 & 11.00 & $8.50 \pm 2.04$ & $12.16 \pm 1.82$ & 6.55 \\
\hline
\end{tabular}

ini dapat digunakan sebagai induk penjenis untuk menghasilkan induk pokok.

Nilai heritabilitas nyata populasi F-3 benih ikan nila biru dicantumkan pada Tabel 3. Populasi F-3 benih ikan nila biru mempunyai nilai heritabilitas nyata sebesar 0,81 . Nilai ini lebih tinggi dibanding nilai heritabilitas nyata F-2 ikan nila biru sebesar 0,41 dengan respons seleksi $14,85 \%$. Pada seleksi ikan nila tahan salinitas 15-20 ppt di Vietnam, Ninh et al. (2014) mendapatkan nilai heritabilitas pada karakter bobot dari empat generasi berkisar antara 0,27-0,53. CharoKarisa et al. (2006) mendapatkan heritabilitas karakter bobot sebesar 0,38-0,60 pada ikan nila (Oreochromis niloticus) yang dipelihara di kolam tanah dengan pemupukan dan tanpa pakan buatan. Rutten (2005) melaporkan nilai estimasi heritabilitas ikan nila mencapai 0,2. Sedangkan Bolivar \& Newkirk (2002) melaporkan nilai heritabilitas bobot ikan nila hasil seleksi famili diketahui sebesar 0,50 dan 0,56. Dari hasil pengamatan atas 13 generasi ikan nila GIFT yang dilakukan pemuliaan di Vietnam, Trong et al. (2013) mendapatkan nilai heritabilitas yang tinggi untuk karakter bobot panen dan pertumbuhan namun rendah untuk karakter faktor kondisi dan bentuk badan.

Menurut Falconer \& Mackay (1996), nilai heritabilitas $\left(h^{2}\right)$ karakter kuantitatif pada ikan terdiri atas tiga tingkatan yaitu: rendah $(0-0,1)$, sedang $(0,1-0,3)$, dan tinggi $(0,3-1,0)$. Sementara itu, Noor (2004) membagi nilai heritabilitas menjadi rendah $(0-0,20)$, sedang $(0,2-0,4)$, dan tinggi (lebih dari 0,4). Dengan demikian, nilai heritabilitas pada benih ikan nila biru pada penelitian ini dapat dikategorikan tinggi.

Nilai heritabilitas yang tinggi ini selaras dengan respons seleksi dari generasi sebelumnya sebesar $22,74 \%$. Hal ini sesuai dengan pernyataan Warwick et al. (1995) yang memprediksi adanya kenaikan kema-

Tabel 3. Respons seleksi, diferensial seleksi, dan heritabilitas nyata benih ikan nila biru F-3 pada umur 90 hari

Table 3. Response of selection, selection differential, and real heritability of F-3 population of blue tilapia at 90 days old

\begin{tabular}{cccccc}
\hline \multicolumn{2}{c}{$\begin{array}{c}\text { Rerata bobot individu } \\
\text { Individual weight }(\mathrm{g})\end{array}$} & $\begin{array}{c}\text { Respons seleksi } \\
\text { Response of selection }\end{array}$ & $\begin{array}{c}\text { Diferensial seleksi F-2 } \\
\text { Selection differential of F-2 }\end{array}$ & $\begin{array}{c}\text { Heritabilitas nyata F-3 } \\
\text { Real heritability of F-3 }\end{array}$ \\
\cline { 1 - 3 } $\begin{array}{c}\text { F-3 seleksi } \\
\text { F-3 selection }\end{array}$ & $\begin{array}{c}\text { F-3 kontrol } \\
\text { F-3 control }\end{array}$ & $\mathrm{g}$ & $\%$ & & \\
\hline 11.58 & 8.95 & 2.63 & 22.74 & 3.24 & 0.81 \\
\hline
\end{tabular}


juan genetik rata-rata sebesar $10 \%$ pada setiap generasi hasil kegiatan seleksi. Gustiano et al. (2008) melaporkan genetic gain sebesar $17,20 \%$ pada ikan nila GIFT. Ponzoni et al. (2004) menyatakan bahwa estimasi nilai heritabilitas bobot ikan mencapai $0,34 \pm$ 0,069; dengan respons seleksi per generasi dapat mencapai $10 \%$.

Kasno et al. (1989) menyatakan bahwa heritabilitas akan lebih bermanfaat bila dipandu dengan simpangan baku fenotipik dan intensitas seleksi untuk mengetahui kemajuan genetik atau respons seleksi suatu karakter. Nilai heritabilitas tinggi yang diikuti oleh respons seleksi tinggi merupakan hasil kerja gen aditif. Sebaliknya suatu sifat yang memiliki nilai heritabilitas tinggi dan diikuti dengan respons seleksi rendah akibat pengaruh gen bukan aditif (dominan, epistasis). Kemajuan genetik harapan merupakan tolak ukur dalam persen dari pergeseran nilai tengah populasi dari kondisi populasi sampai kondisi setelah dilakukan seleksi, dengan memakai asumsi nilai besaran diferensial seleksi.

\section{KESIMPULAN}

Populasi benih ikan nila biru F-3 mempunyai performa pertumbuhan lebih baik dibandingkan nila biru non-seleksi. Nilai heritabilitas benih nila biru populasi F-3 termasuk tinggi, yakni 0,81 dengan peningkatan mutu genetik sebesar 22,74\%.

\section{DAFTAR ACUAN}

Bahar, H., \& Zen, S. (1993). Parameter genetik pertumbuhan tanaman, hasil dan komponen hasil jagung. Zuriat, 4(1), 4-7.

Balarin, J.D., \& Haller, R.D. (1982). Commercial tank culture of tilapia. In Fishelson, L., \& Yaron, Z. (Eds.), International Symposium on Tilapia in Aquaculture. Tel Aviv University. Israel, p. 473-483.

Bolivar, R.B., \& Newkirk, G.F. (2002). Response to within family selection for body weight in nile tilapia, Oreochromis niloticus, using a single-trait animal model. Aquaculture, 204, 371-381.

Charo-Karisa, H., Komen, H., Rezk, M.A., Ponzoni, R.W., van Arendonk, J.A.M., \& Bovenhius, H. (2006). Heritability estimates and response to selection for growth of nile tilapia (Oreochromis niloticus) in low-input earthen ponds. Aquaculture, 261, 479-486.

Courtenay, W.R.Jr., Hensley, D.A., Taylor, J.N., \& McCann, J.A. (1984). Distribution of exotic fishes in the continental United States. p. 41-77. In Courtenay, W.R.Jr., \& Stauffer, J.R.Jr. Distribution, Biology and Management of Exotic Fishes. Johns Hopkins University Press. Baltimore.

Falconer, D.S. (1981). Introduction to quantitative genetics. $2^{\text {nd }}$ edition. Longman, Inc. United Kingdom.

Falconer, D.S., \& Mackay, T.F.C. (1996). Introduction to quantitative genetics. $4^{\text {th }} \mathrm{Ed}$. Longman, England.

Gilles, R. (1987). Volume regulation in cells of euryhaline invertebrates. In cell volume control: fundamental and comparative aspects in animal cells. (Ed. A. Kleinzeller), 30, 205-247. New York Academic Press.

Gjedrem,T. (2005). Selection and breeding programs in aquaculture. Springer. Netherlands. p. 23-32.

Gustiano, R., Arifin, O.Z., \& Nugroho, E. (2008). Perbaikan pertumbuhan ikan nila (Oreochromis niloticus) dengan seleksi famili. Media Akuakultur, 3(2): 8.

Kasno, A., Basri, A., Matjik, A.A., Salahudin, S., Somaatmadja, S., \& Subandi. (1989). Telaah interaksi genotype $\mathrm{x}$ lingkungan pada kacang tanah. Pendugaan parameter genetik hasil dan komponen hasil kacang tanah (Arachis hypogaea Merr.). Penelitian Palawija, 2(2), 81-88.

Kamel, E.A., Elghobashy, H.A., \& Farag, M.A. (2008). Performance of growth and survival rates of Oreochromis aureus juveniles during hard winter condition in Egypt. $8^{\text {th }}$ International Symposium on Tilapia in Aquaculture. p. 319-327.

Ninh, N.H., Thoa, N.P., Knibb, W., \& Nguyen, N.H. (2014). Selection for enhanced growth performance of nile tilapia (Oreochromis niloticus) in Brackish Water (15-20 ppt) in Vietnam. Aquaculture, 428429, 1-6.

Noor, R.R. (2004). Genetika ternak. Penebar Swadaya. Jakarta, 200 hlm.

Pinaria, A., Baihaki, A., Setiamihardja, R., \& Daradjat, A.A. (1995). Variabilitas genetik dan heritabilitas karakter-karakter biomassa 53 genotipe kedelai. Zuriat, 6(2), 88-92.

Ponzoni, R.W., Hamzah,, A. \& Kamaruzzaman, N. (2004). Selection for live weight in the GIFT strain of nile tilapia. In Bolivar, R.B., Mair, G.C. \& Fitzsimmons, K. (Eds.), New dimensions in farmed tilapia. Proceedings $6^{\text {th }}$ International Symposium on Tilapia in Aquaculture. Manila, 12-16 Sept. 2004. p. 42-52.

Rutten, M.J.M. (2005). Breeding for improved production of nile tilapia (Oreochromis niloticus). Wageningen University Dissertation No. 3751.

Shafland, P.L., \& Pesytrak, J.M. (1982). Lower lethal temperatures for fourteen non native fishes in Florida. Environmental Biology of Fishes, 7(2), 149156.

Singh, R.K., \& Chaudary, B.D. (1977). Biometrical methods in quantitative genetics analysis. Kalyani Publishers. Indiana New Delhi, 304 pp. 
Tampake, H., Pramono, D., \& Luntungan , H.T. (1992). Keragaman fenotipik sifat-sifat generatif dan komponen buah beberapa jenis kelapa di lahan gambut pasang surut, Sumatera Selatan. Buletin Balitka, 18, 21.

Tave, D. (1993). Genetic for fish hatchery managers. $2^{\text {nd }}$ ed. AVI. Publishing Company. Inc. Connecticut.

Tave, D. (1995). Selective breeding programmes for medium-sized fish farm. Roma.
Trong, T.Q., Mulder, H.A., van Arendonk, J.A.M., \& Komen, H. (2013). Heritability and genotype by environment interaction estimates for harvest weight, growth rate, and shape of nile tilapia (Oreochromis niloticus) grown in River Cage and VAC in Vietnam. Aquaculture, 384-387, 119-127.

Warwick, E.J., Astuti, J.M., \& Wardjosubroto, W. (1955). Pemuliaan ternak. Gadjah Mada University Press. Yogyakarta, $485 \mathrm{hlm}$. 